\title{
New media, first time voters and the 2007 Australian federal election
}

\author{
GWYNETH HOWELL * \\ University of Western Sydney \\ BRUCE DA SILVA ** \\ University of Western Sydney
}

\begin{abstract}
Researchers suggest that young people of today have disengaged from the political landscape in Australia. However, the online realm provides potential first time voters an avenue in which to engage in politics in an environment that is generally associated with a youthful demographic. New media tactics utilised during the 2007 Australian federal election aimed to not only attract youthful voters, but also to educate and deliver policy on a level generally associated with the 18-24 demographic. This study explored the effectiveness of new media in the political communication context, in particular with relation to first time voters. This research found that first time voters were not as engaged as predicted, and that the third party sites were more popular with undecided voters than the formal political party sites in voter influence.
\end{abstract}

\section{Introduction}

Researchers suggest that politicians are faced with the disengagement of youth from politics. The online realm provides potential first time voters an avenue in which to engage in politics, in an environment which is generally associated with a youthful demographic (Xenos \& Foot, 2008; Montgomery, 2008). Today, with 76.5 per cent of 15-24 year old Australians (Australian Bureau of Statistics, 2008) logging onto the internet on a regular basis, the online realm, in particular new media, has become an important element for political campaign practitioners to communicate and interact with potential first time voters (Montgomery, 2008; Rheingold, 2008).

New media strategies were implemented in the US during the 2000 and 2004 presidential elections. Both the 2000 and 2004 presidential election campaigns exhibited many forms of government driven new media tactics as well as many forms of online civil society (Chen \& Walsh, 2009). In 2004, 'Citizen Change' was formed by rap star Sean 'P. Diddy' Combs employing a variety online tactics utilising commercial websites to encourage the youth of America to fulfil their democratic right to vote - a notion which was echoed through their campaign slogan "Vote or Die!" (Montgomery, 2008). The 'Rock the Vote' program launched by US music industry used software applications, wireless technologies and commercial web sites to encourage young voters to employ their democratic right to vote (Montgomery, 2008). These programs illustrate the innovative trends which have redefined political campaigns. New media tactics provide a direct means for political campaign practitioners - representing both government and third party groups - to engage with potential voters. (Macnamara, 2008; Chen \& Walsh, 2009) 
The 2007 Australian federal election established innovative trends for future election campaigns. Further, this also demonstrated the rapid growth of new media with Web 2.0 technologies in the dissemination of party policy to the first time voter demographic. Chen and Walsh (2009) suggest that "for the major parties, the campaigns showed a higher degree of co-ordination across media than at the last national election, demonstrating new sophistication, but is also reflective of centralisation trends within the parties" (p. 3). Flew (2008a) asserts that the windfall of using Web 2.0 technologies such as social network media forums assisted not only in the construction of social networks and social capital, but also the distribution of knowledge and information as well as "enabling of new modes of democratic participation in public life" (p. 51). Web 2.0 developments such as Facebook, MySpace and YouTube allowed political parties to communicate and interact with potential first time voters in an effort to be seen as fresh, innovative and in touch as well as ultimately encouraging youth participation within the political sphere (Macnamara, 2008). This research study sought to explore the online developments in terms of first time voters and how they engaged with new media in terms of the federal political campaigns in 2007.

New media tactics utilised during the 2007 Australian federal election had two goals (Cooke, 2008a, 2008b). First, to attract youthful voters and second, to educate and deliver policy on a level generally associated with the 18-24 demographic. With 51 per cent of users aged 13-24 spending their time online browsing through social network media sites (Breakenridge, 2008), Web 2.0 developed technologies presented an opportunity for political campaign practitioners to engage with first time voters (Montgomery, 2008). Chen (2008) suggests that social network media sites such as MySpace may not directly influenced votes. However the use of social networking sites did assist to position a party's brand. "Did MySpace pull votes, not directly, but did the constant mention of Labor's new MySpace strategy help position the candidate's brand, then yes" (Chen, 2008, p.18).

\section{The YouTube election}

In 2007, then Prime Minister John Howard pioneered the digitisation of political campaigns, being the first Australian Prime Minister to utilise new media in the form of a personal website, to communicate with constituents (Macnamara \& Bell, 2008). In July 2007, prior to the announcement of the 2007 federal election, Howard revolutionised the political campaigns forum, uploading a video on social network forum YouTube. The Liberal Party attracted widespread observation and opinion through both online and mainstream media. In reaction, the then opposition leader, Kevin Rudd, also produced online videos, a tactic which also attracted widespread observation and opinion. The 'YouTube Election' (2007) was born, with both major parties employing YouTube channels as well as Facebook and MySpace profiles for electoral candidates and finally updated party/personal websites. The 2007 Australian federal election became a battle of 'friends', as users of these Web 2.0 sites befriended candidates or political parties through social network profiles or channels. Such ideology was questioned by the media, "In political MySpace popularity stakes, you would have to say Mr Rudd is streets ahead of Mr Howard. Yesterday afternoon, the Opposition Leader had more than 800 friends, while the Prime Minister had a measly seven. And most of them were fellow Liberal MPs" (Berkovic, 2007, para. 4). This mainstream media coverage increased the interest and traffic for the digital campaigns of both Labor and Liberal.

Kissane (2008) suggests that "the 2007 Australian federal election was the first in which the online campaign and Web 2.0 technologies moved into the mainstream" (p. 1). The 2007 Australian federal election established an innovative precedent within the Australian political 
sphere, as online political campaigns became a prominent tactic to communicate and interact with a more diverse, and most importantly, youthful audience (first time voters).

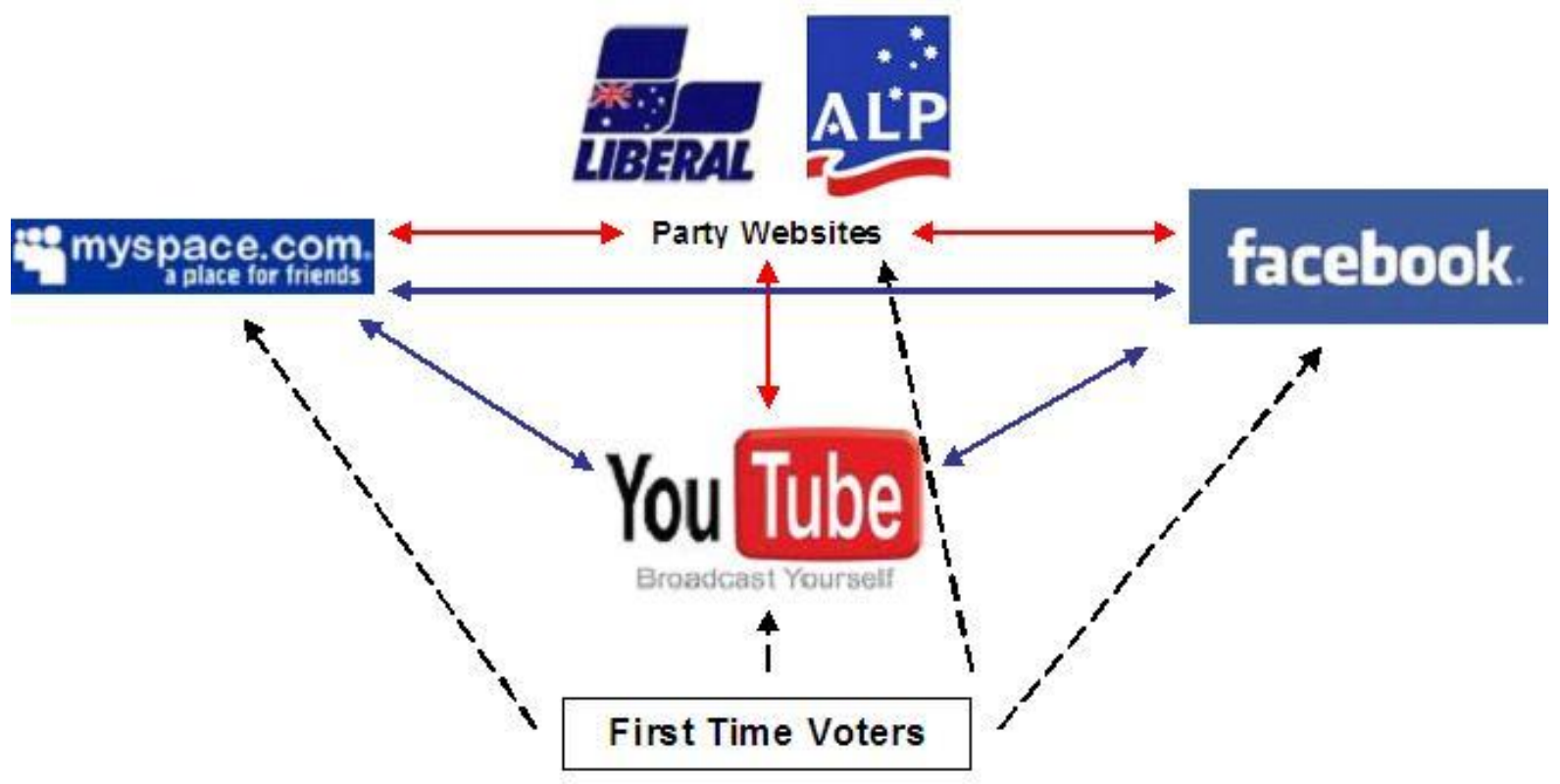

Figure 1. First time voters; during the 2007 federal election, became exposed to campaign information via various new media outlets. However, the variety of online interpretations (YouTube, MySpace and Facebook) inevitably was derived from a singular source (party websites), which circulated information throughout all new media outlets attributed by any respective party utilising new media.

\section{JohnHoward2007}

The Liberal Party of Australia initiated the election campaign online, with former Prime Minister John Howard announcing Liberal Party policy concerning the fight on climate change via YouTube several months before the Coalition's announcement of the 2007 Australian federal election (Macnamara \& Bell, 2008). The Liberal Party of Australia established 'JohnHoward2007' - Liberal Party YouTube Channel - in July 2007, in an effort to communicate and interact with citizens. This tactic was used to archive content in a forum which can be revisited at any time and commonly visited by users aged 13-24 (Seitz, 2008; Breakenridge, 2008). John Howard's personal website (www.pm.gov.au) was redirected to the official Liberal Party of Australia website which shared links to various YouTube videos uploaded during the course of the 2007 Australian federal election campaign (Macnamara \& Bell, 2008). The Liberal Party also established a variety of other new media tactics in which to communicate with first time voters including a variety MySpace and Facebook profiles as well as campaign specific websites (Macnamara \& Bell, 2008; Pandora, 2007).

\section{Kevin07}

The Australian Labor Party forged an online campaign for the 2007 Australian federal election designed specifically to provide a "“route to youth' - especially approaching first and second time voters in the online places [Facebook, MySpace and YouTube] they expect to be approached" (Cooke, 2008a, p. 1). Labor's online campaign centred on a single campaign website - 'Kevin07' - which offered a video channel - 'australianlabor' (ALP YouTube Channel) - and links to social networking media sites such as Facebook and MySpace (Kissane, 2008). 'Kevin07' encouraged users to participate in a campaign blog regarding specific issues or policies surrounding the election as well as the option to sign up to ' $\mathrm{K}$ - 
Mail' - an email delivered news item (Kissane, 2008). Moreover visitors could also purchase branded merchandise, including bumper stickers and t-shirts (Kissane, 2008).

Macnamara (2008) asserts that 'Kevin07' achieved success both online and offline, with the mainstream media positively analysing the ALP's online campaign as beneficial for both the political sphere and potential first time voters. Taylor (2007) suggests "Australia's election has become a war of bytes, with Labor challenger Kevin Rudd swooping on the Internet's high ground to build an army of young supporters and a Facebook fan club on a promise of 'fresh thinking'" (Reuters, 2007, para. 17). 'Kevin07' was a highly interactive site launching daily blogs as well as incorporating features from the various social networking sites Facebook, MySpace and YouTube - to establish a truly effective campaign site (Macnamara $\&$ Bell, 2008).

\section{Research Purpose}

Presently, there is little empirical investigation on the effectiveness of new media in the political communication context, in particular in relation to first time voters. The new media tactics utilised by both the Australian Labor Party and Liberal Party of Australia were identified to approach first time voters in the online places in which they expect to be approached. (Cooke, 2008a, 2008b). This research explores and maps the content of these new media websites used in the 2007 federal election - including those posted on the social network forums YouTube, MySpace and Facebook - targeting the first time voter demographic. Such research identifies the transformation of public communication in political campaigns as well as the impact of new media tactics within the political sphere by identifying the potential effects, risks and opportunities to improve public access to information and political processes.

This research project endeavoured to answer the question: Did the new media tactics employed by the Australian Labor Party and Liberal Party of Australia in the 2007 Australian federal election influenced first time voters?

\section{Method}

Data was collected from various new media sites utilised by the ALP and Liberal Party, from social network sites YouTube, MySpace and Facebook, as well as official websites and various campaign specific websites. In total, 10 new media sites were collated for the purpose of the research project (five Labor, five Liberal). These web sites formed the basis of the treatments to be measured by the instrument. The first page of each web site was presented as a colour printed document. Then a self-administered survey questionnaire comprised of 64 questions in three sections was distributed among a sample of 18-24 year-olds.

Marketing scale measures were used to measure the perceived attitudes of the respondents to the selected new media tactics. Of the 64 questions, 56 presented scaled data, which were measured through a five point ranking system, ranging from 'definitely disagree' to 'definitely agree'. The remaining questions attributed data through nominal selections, providing an opportunity for respondents to provide further input into preconceived voting patterns as well as the impact of new media tactics on their impending decision. To establish the instrument's internal validity, the reliability and validity of the questions posed, the instrument was tested in a pilot study; and the measures (scales) used were deemed applicable to what was measured (c.f. Bruner, Hensel \& James, 2005). 


\section{Sample}

This exploratory study employed a convenience sample. This non-probability method was employed during this initial stage of research to obtain a gross estimate of the results (Aaker, Kumar, Day \& Lawley, 2005; Sarantoakos, 1998). The sample frame for the study was drawn from a population of individuals who were students at a university in Sydney, Australia. This sample was highly appropriate for the study as research indicates university students are heavily reliant on the Web, not only with regards to their studies but also with the majority of 18-24 year olds spending large amounts of leisure time online (Flew, 2008b; Montgomery, 2008; Australian Bureau of Statistics, 2008). Further, the respondents selected were all first time voters in the 2007 Australian federal election. A screening question was used at the beginning of data collection to define first time voters.

\section{Sample Size}

The sample size for the pilot study $(n=20)$ and for the main experiment $(n=170)$ are deemed adequate for the type of analysis to be performed (Sarantakos, 1998). Using the data collected during the pilot study the researcher confirmed support for the assumption of normal distribution of the data.

\section{Missing Data}

According to Malhotra, Hall, Shaw and Oppenheim, using pair-wise deletion for missing data is considered appropriate if "the sample size is large, there are few missing responses and the variables are not highly related" (2002, p. 447). The data collected for this study met these three conditions. To manage missing data, the researcher used only the respondents with complete responses for each of the calculations.

\section{Analysis Tools}

In order to test the credibility of the new media sites, SPSS 15.0 was used to analysis the data collected. The research sought to measure which new media tactics was perceived as "most credible".

\section{Results}

The final sample size for the study, n=170, was considered adequate for exploratory analyses (Alreck \& Settle, 1995). Sixty-six per cent (66\%) of subjects were female, and the majority was in the first year of their undergraduate degree. All but one subject were aged 18-24 years.

Prior to the Australian federal election announcement 64.1 per cent $(n=109)$ of respondents, had already decided on whom they would support in the election. There were 37.1 per cent of respondents supporting a Labor victory $(n=63)$, whilst 27.1 preferred a return to government for the Liberal Party $(n=46)$. However, $35.9(n=61)$ per cent of respondents were indecisive in their preference, and as the research suggests, most likely to be influenced by new media tactics (Montgomery, 2008).

A MANOVA applied to the perceived credibility scores found significant differences as a function of the web site exposure $(\mathrm{F}=36.8, \mathrm{df}=2, \mathrm{p}<.001)$. As the MANOVA indicated there were significant differences between groups, multiple range tests were conducted post-hoc to ascertain which web site produced the best result in terms of positive intention to vote for that party by indecisive voters. The Kevin07 site (3.5) produced the most favourable intention to vote $(p<0.05)$. Yet, only 10 per cent $(n=17)$ of the entire pool of participants $(n=170)$, were 
influenced by new media tactics employed by political parties during the 2007 Australian federal election.

Further only 29.4 per cent $(n=50)$ of respondents visited any new media site generated by the ALP or Liberal Party. The study also found that 35.9 per cent $(n=61)$ of respondents not to visit a single new media site relating to the 2007 Australian federal election. In terms of direct contact via the Party's traditional site and third party sites, 49.2 per cent $(n=59)$ of respondents who chose to not to visit a party website, but did engage with new media via third party websites. YouTube was identified as the most popular new media outlet visited by first time voters in this study, with Facebook (26\%) and MySpace (21\%). This suggests that third party new media sites could be the vanguard of election campaign information for first time voters, as opposed to the online tactics employed by political parties. The findings from this study support Macnamara's (2008) argument that the majority of first time voters avoided direct contact with political party online tactics. These respondents used new media sites operated by third party groups to gain a greater understanding of the ideology behind the concepts and policies of all the respective political groups involved in an election.

\section{Limitations}

This exploratory study focused a particular campaign, so caution must be used in any generalisation of the findings. Furthermore, as there were only 170 respondents in the final study this is not adequate for generalisation. However, it provides an interesting outcome to be further investigated. Also the differences in web pages in terms of the length and creativity of content could not be accounted for and should be investigated in future research.

\section{Discussion}

This research study refutes the assumption that a majority of first time voters interacted with online political content during the 2007 Australian federal election (Berkovic, 2007; Lee, 2007; Best, 2007; Peatling, 2007; Osborne, 2007a, 2007b; Cooke, 2007a, 2007b). Further, the results indicate that while the Australian Labor Party and Liberal Party of Australia provided Australian citizens their first glimpse at election campaigning streaming online, it was not as effective in utilising new media to approach first time voters in areas they expected to be approached (Cooke, 2008a, 2008b). Chen (2008) suggests that while new media tactics employed represent political policy and information, the innovative form of communication was an attempt to interact with young voters. These new media tactics only appealed to first time voters who were decisive in preference of a political party. Chen's (2008) observation confirms that the lack of first time voters engage with new media during the 2007 Australian federal election, with only a minute segment of first time voters decisive of their voting decision choosing to interact directly with online political campaign material. Chen (2008) and Macnamara (2008) both raised concerns in the practice of new media during the 2007 Australian federal election, both asserting that the online credibility of the ALP's new media tactics were significantly higher than the online techniques utilised by the Liberal Party supporting the results of this study.

Further investigation reaffirmed the lack of online credibility established throughout the new media tactics employed by the Liberal Party of Australia. Not a single respondent was influenced by their new media tactics. Researchers suggest that that the new media tactics employed by the Australian Labor Party held greater potential to influence the decisionmaking process of first time voters, as opposed to the online techniques utilised by the Liberal Party of Australia (Chen, 2008; Macnamara, 2008). 
According to Kissane (2008), the 2007 Australian federal election established the foundations for the usage of new media sites. It is suggested that this tactic will increase in prominence within the Australian political sphere. "The online push and particularly its focus on social networking and user-generated content and commentary - was aimed at young voters and most MSM [mainstream media] sources noted the deliberate push by Rudd and the ALP to attract the youth vote" (Kissane, 2008, p.6). However, while Kissane (2008) asserts the 2007 Australian federal election as a significant stepping stone in the development of new media campaigning within political elections, the data collected in this study contradictors the assumption that first time voters largely visited political new media sites during the 2007 Australian Election campaign (Berkovic, 2007; Lee, 2007; Best, 2007; Peatling, 2007; Osborne, 2007a, 2007b; Cooke, 2007a, 2007b).

Chen (2008) acknowledges that "younger voters are (on average) more tractable to change, they are a better market than other voters and those who are 'rusted on' (p. 13). As new media is a good segmentation tool, there's a clear fit." However, a potential motive in terms of why the majority of first time voters did not log onto political party new media sites is that social networking media sites are attracting 'likeminded people' to engage in new media tactics. So while the 18-24 voters are identified as the heaviest users of Web 2.0 (Reigner, 2007), those seeking political new media sites are only those with an avid interest in the outcome of the 2007 Australian federal election. Not because they utilise Facebook, MySpace and/or YouTube on a regular basis.

This finding suggests that further research is required to measure the attitudes and opinions of first time voters in relation to the findings established in this study. Further, research will inform online content designed to enhance the interactivity and overall online credibility of political party new media sites.

\section{Conclusion}

A key consideration is whether new media tactics employed by political campaign practitioners directly target youthful voters are influential (Montgomery, 2008; Rheingold, 2008; Xenos \& Foot, 2008). Whilst theorists support this presumption, this study suggests that unlike the tactics employed within the US political sphere, first time voters in Australia remain sceptical to sincerity and credibility of online tactics in communicating political policy and information. The principle aim of this study was to provide insight into the opinions and attitudes of first time voters in relation to the new media tactics employed during the 2007 Australian federal election, and this was achieved. Further, this study challenges the preliminary application of new media within the Australian political sphere, questioning the online credibility of a preponderance of new media tactics employed during the 2007 Australian federal election. The lack of first time voter engagement with political online tactics; suggests that further research is needed to significantly document why the aspects of the political party new media tools were ineffectively penetrating in the first time voter demographic.

New media tactics enable political practitioners the opportunity to interact with first time voters, through a medium generally associated with a youthful demographic (Montgomery, 2008). Xenos and Foot (2008) assert that online techniques represent the future for political communication. However, the key implication of this study is that the impact of new media on the first time voter demographic far less than the predictions made prior to the 2007 Australian federal election. Therefore, prior to the next election, further research should be undertaken to explore the best way to engage with this key voter demographic.

Public Communication Review, Vol. 1, 2010. 


\section{References}

Aaker, D., Kumar, V., Day, G., \& Lawley, M. (2005). Marketing Research. Milton, Queensland: Wiley

Election war of words goes online. (2007, October 18). ABC News Online. Retrieved April 10, 2008, from http://www.abc.net.au/news/stories/2007/10/18/2062497

Alexa. (1996). Australian Traffic Rankings. Retrieved August 17, 2008, from http://www.alexa.com

Australian Bureau of Statistics (2008). Australian social trends, 2008. Retrieved August 16, 2008, from http://www.abs.gov.au/AUSSTATS/abs@.nsf/Lookup/4102.0Chapter10002008

Australian Democrats (2008). Federal election youth poll results: Youth Poll Election '07. Australian Democrats. Retrieved April 10, 2008, from http://www.democrat.org.au

Azhar, A. (2007, July 27). When politicians invade MySpace. B\& T Weekly, 8. Retrieved April 10, 2008, from the ProQuest database.

Berkovic, N. (2007, July 13). Kevin has more 'friends' than John. The Australian. Retrieved September 1, 2009 from www.theaustralian.com.au/story/0,20867,22065976-2702,00.html

Best, J. (2007, August 8). Rudd calls on Facebook mates in campaign. ZDNet Australia. Retrieved October 24, 2007, from http://www.zdnet.com.au/news/business

Bickman, L., \& Rog D. (1998) Handbook of applied social research methods. Thousand Oaks, CA: Sage Publications.

Bradburn, N., \& Mason, W. (1964). The effect of question order on responses. Journal of Marketing Research, 1(4) 57. Retrieved May 16, 2008, from the ProQuest database.

Breakenridge, D. (2008). PR 2.0: New media, new tools, new audiences. New Jersey: Pearson Education, Inc.

Bruner, G., Hensel, P., \& James. K. (2005). Marketing scales handbook: A compilation of multi-item measures. Chicago, IL: American Marketing Association. Cambridge, Massachusetts: The MIT Press.

Chen, P. (2008). Australian political parties use of YouTube 2007. Communication, Politics \& Culture, 4l(1).

Chen, P., \& Walsh, L. (2009). E-election 2007? Political competition online. Australian Cultural History, October 2009, 26(2).

Cooke, D. (2007a, October 16). PM gets video makeover. Sydney Morning Herald. Retrieved October 24, 2007, from http://www.smh.com.au/articles/2007/10/15/1192300663218.html

Cooke, D. (2007b, October 18). Who's your top friend - Kevin or John? The Age. Retrieved December 10, 2007, from http://www.theage.com.au/articles/2007/10/18/1192300942990.html

Cooke, C. (2008a). Kevin07 - the digital aftermath. B\&T Magazine Online. Retrieved August 8, 2008, from http://www.bandt.com.au

Cooke, C. (2008b, June). The Kevin07 digital campaign. Paper presented at CCI: Creating Value Between Commons and Commerce, Brisbane.

Crawshaw, D. (2007, July 20). Fed politicians risk dignity in search for new audiences. AAP General News Wire, 1. Retrieved May 16, 2008, from the ProQuest database.

Crook, E. (2007). The 2007 Australian Federal election on the internet. Retrieved April 8, 2008, from National Library of Australia.

Crook, E. (2007) The 2007 Australian federal Election on the Internet. Canberra: National Library of Australia.

Davies, W. (2003). You don't know me but ... Social capital and social software. London: iSociety.

Dean, K. (2005). Blogging + Video = Vlogging. Retrieved May 3, 2008, from http://www.wired.com

Drezner, D., \& Farrell, H. (2004). The power and politics of blogs. University of Chicago \& George Washington University.

Evans, M. (2007). Virgin voters. election tracker. Retrieved April 18, 2008, from http://www.electiontracker.net.au/virgin-voters

Facebook. (2004). About us. Retrieved April 10, 2008, from http://www.facebook.com

Farmer, B. \& Benoit, G., (2007) How the internet is changing political campaigning. The New American 23(20), 12-17.

Feagin, J., Orum, A., \& Sjoberg, G. (Eds.) (1991). A case for case study. Chapel Hill, NC: University of North Carolina Press. 
Flew, T. (2008a) Not yet the internet election: Online media, political commentary and the 2007 Australian federal election. Media International Australia, No. 126, 5-13.

Flew, T. (2008b). New media: An introduction (3rd ed.). South Melbourne: Oxford University Press.

Hearn, L. (2007, July 18). Howard Clip becomes spam magnet. The Age. Retrieved May 26, 2008, from http://www.theage.com.au

Hills, R. (2007, October 21). Video wars rock the vote. The Age. Retrieved January 1, 2008, from http://www.theage.com.au/articles/2007/10/20/1192301102946.html

Howell, D. (2002). Statistical methods for psychology (5th ed.). Belmont, CA: Thomson Wadsworth

Jaeger, R. (1990). Statistics: A spectator sport (2nd ed.). Thousand Oaks, CA: Sage

Kissane, D. (2008). Chasing the youth vote Kevin07, Web 2.0 and the 2007 Australian federal election. Politics : Web 2.0 - An International Conference. Royal Holloway, University of London, 17-18 April.

Lee, S. (2007. July 15). Rudd's MySpace fully sick. The Daily Telegraph. Retrieved October 24, 2007, from http://www.news.com.au/dailytelegraph/story/0,,22074980-5001031,00.html

Macnamara, J. (2008). Emergent media and what they mean for society, politics and organisations. UTSPEAKS public lecture. Retrieved September 12, 2009 from http://74.125.153.132/search?q=cache:jXDH_jZDaLAJ:www.uts.edu.au/new/speaks/2008/June/res ources/1106-talk.pdf+macnamara+2008+new+media+and+politics\&cd=1\&hl=en\&ct=clnk\&gl=au

Macnamara, J., \& Bell, P. (2008). E-Electioneering: Use of new media in the 2007 Australian Federal Election. Research report. Sydney: University of Technology Sydney, Australian Centre for Public Communication.

Malhotra, N., Hall, J., Shaw, M., \& Oppenheim, P. (2002). Marketing research. Frenchs Forest: Pearson Education Australia.

Montgomery, K. (2008). Youth and digital democracy: Intersections of practice, policy, and the marketplace. In W. Lance Bennett (Ed.), Civic life online: learning how digital media can engage youth (pp. 25-49). Cambridge, Massachusetts: The MIT Press.

Mullner, R., Levy, P., Byre, C., \& Matthews, D. (1982). Effects of characteristics of the survey instrument on response rates to a mail survey of community hospitals. Public Health Reports, (97) 465-469.

MySpace. (2003). About us. Retrieved April 10, 2008, from http://www.myspace.com.au

Neuman, W. (1997). Social research methods: Qualitative and quantitative approaches (3rd ed.). Boston, MA: Allyn and Bacon

Osborne, D. (2007, November 23). Election 2007 and the web. AAP. Retrieved December 10, 2007, from http://www.aap.com.au

Osborne, D. (2007, September 21). Fed: Internet becomes the new political battleground. AAP General News Wire, 1.

Pandora (2007). 2007 Australian federal election campaign - media, comment and video web sites Australian internet sites. Retrieved October 1, 2009, from http://pandora.nla.gov.au/col/c9124

Patton, M. (2002) Qualitative research and evaluation methods (3rd ed.). Thousand Oaks, CA: Sage Publications

Peatling, S. (2007, September 17). Labor seeks YouTube election debate. Sydney Morning Herald. Retrieved January 4, 2008, from http://www.smh.com.au

Riegner, C. (2007). Word of mouth on the web: The impact of Web 2.0 on consumer purchase decisions. Journal of Advertising Research, 436-447.

Rheingold, H. (2008). Using participatory media and public voice to encourage civic engagement. In W. Bennet (Ed.), Civic life online: Learning how digital media can engage youth (pp. 97-118). Cambridge, MA: MIT Press.

Sarantakos, S. (1998). Social research (2nd ed.). South Yarra: Macmillan Education Australia.

Schiffman, L., Bednall, D., O’Cass, A., Paladino, A., \& Kanuk, L. (2005). Consumer behaviour. (3rd ed.). Frenchs Forest: Pearson, Prentice Hall.

Seitz, J. (2008). It's an online world for young people and political news. Nieman Reports 66(2), 1011.

The YouTube Election (2007, July 14). Sydney Morning Herald. Retrieved October 29, 2009, from http://www.smh.com.au/2007/07/13/1183833772806.html 
Taylor, R. (2007, November 1). Internet the battleground for Australia's election. Reuters. Retrieved December 10, 2007, from http://www.reuters.com

Xenos, M., \& Foot, K. (2008). Not your father's internet: The generation gap in online politics. In W. Bennett, Civic life online: Learning how digital media can engage youth (pp. 51-70). Cambridge, MA: MIT Press.

Yin, R. (1994). Case study research, design and methods (2nd ed.). Newbury Park, CA: Sage Publications.

* Dr Gwyneth Howell is senior lecturer in public relations at the University of Western Sydney, a position she has held for the past six years. She also has 18 years consulting experience in corporate and marketing communications and public relations. Her main research focus is strategic public relations, crisis and issues management, and social media marketing.

** Bruce Da Silva is a University of Western Sydney Honours graduate in public relations, currently studying for a Masters in Business Marketing at the University of Technology Sydney. Bruce's main research focus is political public relations and emerging public relations tactics. 